\title{
Some Physical and Mechanical Properties of Xylopia aethiopica Fruit
}

\author{
Davies R. M. \\ Department of Agricultural and Environmental Engineering, Niger Delta University, P.M.B 071, Yenagoa, Bayelsa State, Nigeria
}

\begin{abstract}
Xylopia aethiopica is important crop that has medicinal and economic values and commonly utilized traditionally in the treatment of several ailments. Thus, research carried out to investigate the physical and mechanical properties of xylopia aethiopica, namely length, width, thickness, mean diameters, sphericity, surface area, volume, true and bulk densities, porosity, angle of repose and static coefficient of friction, angle of repose, rupture force of xylopia aethiopica at $9.7 \%$ moisture content (w.b.). Also, develop a database for engineers as well as by food scientists, processors and breeders properties of xylopia aethiopica. The average length, width, and thickness varied between 25.13 and $87.60 \mathrm{~mm}, 3.48$ and $5.79 \mathrm{~mm}$, and 2.14 and $4.78 \mathrm{~mm}$. The average sphericity, aspect ratio, surface area, volume, 1000 unit mass bulk and true densities of xylopia aethiopica revealed $15.50 \%, 6.69 \%, 450.38 \mathrm{~g}, 389.31$ $\mathrm{kg} / \mathrm{m}^{3}$ and $873.04 \mathrm{~kg} / \mathrm{m}^{3}$. Detailed information (database) provided will be useful in the design and development of machines to mitigate against stress involved in handling and processing of xylopia aethiopica (Annonaceae) fruit. It is recommended to use stainless steel as materials for equipment construction.
\end{abstract}

Keywords: Axial dimensions; Engineering properties; Coefficient of static friction; Angle of repose; Sphericity; Static coefficient of friction.

(c) () CC BY: Creative Commons Attribution License 4.0

\section{Introduction}

Xylopia aethiopica (Annonaceae), also known as negro pepper, African pepper, guinea pepper and spice tree. Negro pepper is a native to tropical regions of central and Western Africa, an ever green aromatic tree. It sometimes grow up to 15-30 meter high [1]. It is commonly found in the low land rain forests and moist fringe forests in the savanna zones and coastal regions of Africa. It has been found to have medicinal values especially in the treatment of diarrhoea, dysentery; stomach disorder, menstrual disorder, naso-pharyngeal infections, arthritis, rheumatism, infections. Nnodim, et al. [2], reported that the consumption of extract of xylopia aethiopica in males could result in infertility.

Phytomedicine is well known form of alternative medicine [3]. According to the report of World Health Organization (WHO) about $80 \%$ of the world's population depends on unconventional plant-based medicines as their primary medical intervention particularly in the developing [4]. Xylopia aethiopica (Annonaceae) have been reported as one commonly used medicinal plants and this can be adduced to basic information regarding the ethnopharmacology, pharmacology, Toxicological and phytochemistry properties it posses [5-10].

Presently, there is upsurge demand globally for utilization of herbal medicines due to improved laboratory investigation into the pharmacological properties of the bioactivities from natural source and their ability to manage different diseases. Discovery of herbal medicines had generated differentopportunities for several conventional and alternative therapies.

Fundamental engineering information on biomaterial is essential for optimal design of machines.forhandling, transportation, cleaning, sorting, separation, drying, aeration, storing, and processing. This informationon the geometrical characteristics of size, shape, sphericity, volume, surface area, weight, density, and porosity are important needed by engineers as well as by food scientists, processors and breeders [11, 12]. Data on physical properties are important in the design of a particular machine or analysis of the behavior of products in order to perform various post harvest operations [13]. Grading of grains seeds and fruits is relied on the physical characteristics such as size and shape. The handling losses during threshing, separation, cleaning and grading operations are influenced by the size and shape of agricultural materials [13].

Density is commonly used to separate impurities from the agricultural products and to estimate floor space during transportation and storage in food industries. These parameters such as surface area, volume and porosity of biomaterials are imperative in estimations correlated to spray coverage, removal of residues, respiration rate, light reflectance, colour determination, evaluation of the diffusion coefficient of shrinking systems heating and cooling processes and rate of reaction airflow, heat flow and drying. The coefficient of static and dynamic friction on various surfaces is also essential to design the conveying, transporting, and storing machinery. The angle of repose is imperative in designing and development of machinery for mass flow and structures for storage [14-18].

Presently, no detailed or comprehensive studies have beencarried out from available literature on the physical and mechanical properties of xylopia aethiopica. This study was investigated toprovide detailed information on useful data essential for design and development of machines to mitigate against stress involved in handling and processing of xylopia aethiopica (Annonaceae) fruit. 


\section{Materials and Methods}

\section{a. Sample Preparation and Moisture Content Determination}

The xylopia aethiopica (Annonaceae) (Fig. 1) was cleaned to devoid of sand or any other foreign bodies. The sample was packed inside polythene bags and air sealed. The moisture content of the xylopia aethiopica (Annonaceae) was determined by oven drying method as described by ASABE (2003).

\subsection{Geometric Properties}

To determine mean of xylopia aethiopica dimension, 100 seeds were randomly selected and their three linear dimensions namely, length $(L)$, width $(W)$ and thickness $(T)$ were measured using digital Vernier Caliper with an accuracy of $0.01 \mathrm{~mm}$. The average length of xylopia aethiopica were investigated using the three axial dimensions. The arithmetic mean diameter $\left(D_{a}\right)$, geometric mean diameter $\left(D_{g}\right)$, sphericity $(\Phi)$, surface area $S$, aspect ratio $R_{a}$ of xylopia aethiopica were calculated by using the following relationships [11, 19-21]

$$
\begin{aligned}
& \mathrm{Da}=\frac{\mathrm{L}+\mathrm{W}+\mathrm{T}}{3} \\
& \mathrm{Dg}=(\mathrm{LWT})^{-3} \\
& \mathrm{Dsm}=\left(\frac{l W+W T+L T}{3}\right)^{0.5} \\
& \mathrm{De}=\frac{\mathrm{Da}+\mathrm{Dg}+\mathrm{Dsm}}{3} \\
& \Phi=\frac{\sqrt[3]{(L W T)}}{L} \\
& \mathrm{Ra}=\frac{\mathrm{W}}{\mathrm{L}} 100 \\
& \mathrm{As}=\frac{\pi \mathrm{BL}}{(2 \mathrm{~L}-\mathrm{B})} \\
& \mathrm{V}=\frac{\pi \mathrm{B}^{2} \mathrm{~L}^{2}}{6(2 \mathrm{~L}-3)} \\
& \mathrm{B}=(\mathrm{LW})^{0.5}
\end{aligned}
$$

The volume (V) of xylopia aethiopicawas evaluated using the toluene displacement method [21]. The 1000 unit mass of xylopia aethiopica determined using precision electronic balance to an accuracy of $0.01 \mathrm{~g}$. To evaluate the 1000 unit mass for xylopia aethiopica, 50 randomly selected samples were weighed and multiplied by 20 to give the mass of 1000 Xylopia aethiopica. The experiment was replicated five times.

The bulk density $(\rho b)$ of xylopia aethiopica were evaluated using the technique adopted by Koocheki, et al. [19]. The true density ( $\rho t)$ of xylopia aethiopica was evaluated using the water displacement method [11]. Water displacement method was used for Xylopia aethiopica because of its low water absorption characteristic. The porosity of the bulk xylopia aethiopica were evaluated from the values of the bulk density and true density based on the relationship given by Mohsenin [11].

$$
\varepsilon(\%)=\left(1-\frac{\rho b}{\rho t}\right) 100
$$

The static and dynamic coefficient of frictions was determined with respect to six structural materials namely: galvanized iron sheet, rubber sheet, plywood sheet, iron sheet in accordance with Davies, Davies [22]. The angle of repose was determined based on the method used by Davies [23].The mean force required initiating rupture in Xylopia aethiopicain the horizontal and vertical axes were measured using an Instron Testing Machine equipped with a $5 \mathrm{~kg}$ load cell at a compressive rate of $20 \mathrm{~mm} \mathrm{~min}^{-1}$.

\section{b. Statistical Analysis}

The obtained data was statistically analysed using Statistical Analysis System (SAS) (2007) and Microsoft Excel (2007) packages for Analysis of Variance (ANOVA) and descriptive statistics.

\section{Results and Discussion}

The average length, width, and thickness varied between 25.13 and $87.60 \mathrm{~mm}, 3.48$ and5.79 mm, and 2.14 and $4.78 \mathrm{~mm}$ as revealed in Table 1.Arithmetic and geometric mean diameters for xylopia aethiopica ranged from 10.25 to $32.72 \mathrm{~mm}$. Whilesquare mean diameter and equivalent diametervaried from 3.67 to $6.82 \mathrm{~mm}$ and 6.55 to 17.65 $\mathrm{mm}$. The mean length, width and thickness of date palm fruit were $41.06 \pm 2.02 \mathrm{~mm}, 19.24 \pm 2.66 \mathrm{~mm}$ and $16.65 \pm 1.23$ $\mathrm{mm}$ [24]. Mean length, width, and thickness of the apricot fruit as 38.94, 40.92, and $35.21 \mathrm{~mm}$ [25]. The mean geometric and arithmetic mean diameters of bitter kola seeds and nut, palm fruit and kernelranged from 12.38 to $18.15 \mathrm{~mm}$ and 17.46 to $23.69 \mathrm{~mm}$ and 11.94 to $17.28 \mathrm{~mm}$ and 16.91 to $22.75 \mathrm{~mm}$ [12, 26]. The dimensional characteristics are significant in providing essential engineering data necessary for design and development of appropriate machines for grading, sizing, sorting, cleaning and packaging. These parameters determine the natural resting position of any biomaterial.

The average sphericity and aspect ratio of xylopia aethiopica as shown in Table 1 revealed $15.50 \%$ and $6.69 \%$. The low sphericity value indicated that the xylopia aethiopica is not spherical in shape and will tends to slide rather 
than rolling [27].This parameters are very useful in the design of processing and storage equipment, principally in handling operations such as conveying and discharge from chutesforany grain, fruit and seed[13].

Davies and Zibokere [28] reported sphericity of three species of melon seeds was obtained for C. lunatus, 53\%, C. edulis, $47 \%$ and C. vulgaris, $45 \%$.

On the other hand, the surface area of xylopia aethiopica varied from 453.59 to $3556.53 \mathrm{~mm}^{2}$. This parameter is very valuable tool in decisive the shape of any grain, fruit and seed.The average surface area of bitter kola nut and shell were $447.9 \mathrm{~mm}^{2}$ and $898.4 \mathrm{~mm}^{2}$.The mean surface area of gbafilo fruit and kernel ranged from 1584.80 to $2455.90 \mathrm{~mm}^{2}$ and 737.37 to $1378.90 \mathrm{~mm}^{2}$ [28].

This is imperative in the way the grains, fruits andseeds will act upon oscillating surfaces for the period of processing operations [29]. The mean volume was $16187.56 \mathrm{~mm}^{3}$, although the volume spread between 453.59 and $37189.37 \mathrm{~mm}^{3}$. This value is lower to the values reported for ackee apple and oil bean seed [27]. This parameter is practically significance in the design of sowing and sizing machinery.

The 1000 unit mass of xylopia aethiopica was 450.38 g.1000 unit mass was reported for japtropha seed and kernel, arigo seed, simarouba fruit and kernel, maize, red gram, wheat, green gram, chickpea, faba bean, pigeon pea were $1322.41 \mathrm{~g}, 688 \mathrm{~g}, 1124.7 \mathrm{~g}, 1120 \mathrm{~g}, 330.26 \mathrm{~g}, 68.30 \mathrm{~g}, 102 \mathrm{~g}, 346 \mathrm{~g}, 30.15 \mathrm{~g}, 120 \mathrm{~g}$ and $75 \mathrm{~g}$ accordingly [3033].The practical application of this property is found in the design of equipment for cleaning using aerodynamic forces, separation, conveying and elevating unit operations is useful in cleaning. The Porosity,bulk and true densities, bio-yield force, rupture force, deformation at rupture point and compressive force were given in Table 2.

Table-1. Some physical properties of xylopia aethiopica

\begin{tabular}{l|l|l|l|l|l}
\hline Properties & No. of Samples & Maximum & Minimum & Mean & Standard Deviation \\
\hline Length(mm) & 100 & 87.60 & 25.13 & 67.36 & \\
\hline Width(mm) & 100 & 5.79 & 3.48 & 4.24 & \\
\hline Thickness(mm) & 100 & 4.78 & 2.14 & 3.86 & \\
\hline 1000 Unit mass(g) & 50 & 470.41 & 337.82 & 450.38 & \\
\hline Arithmetic Mean Diameter(mm) & 100 & 32.72 & 10.25 & 25.15 & \\
\hline Geometric Mean Diameter(mm) & 100 & 13.40 & 5.72 & 10.44 & \\
\hline Square mean diameter(mm) & 100 & 6.82 & 3.67 & 5.72 & \\
\hline Equivalent diameter $(\mathrm{mm})$ & 100 & 17.65 & 6.55 & 13.77 & \\
\hline Sphericity $(\%)$ & 100 & 15.30 & 22.76 & 15.50 & \\
\hline Surface Area(mm $\left.{ }^{2}\right)$ & 50 & 3556.53 & 453.59 & 2044.91 & \\
\hline Volume $\left(\mathrm{mm}^{3}\right)$ & 100 & 37189.37 & 1922.76 & 16187.6 & \\
\hline Aspect Ratio(\%) & 100 & 6.61 & 13.85 & 6.29 & \\
\hline
\end{tabular}

The mean bulk and true densities of xylopia aethiopica were $389.31 \mathrm{~kg} / \mathrm{m}^{3}$ and $873.04 \mathrm{~kg} / \mathrm{m}^{3}$. True and bulk densities of arigo were $1066.7 \mathrm{~kg} / \mathrm{m}^{3}$ and $989.78 \mathrm{~kg} / \mathrm{m}^{3}$. There is significant difference in the values of true and bulk densities of the arigo seeds and simarouba [32].The bulk and true densities of agricultural products play major role in the design of silos, calculation of thermal properties in heat transfer problems, in estimating Reynolds number in pneumatic and hydraulic handling of materials, calculation of floor space during transportation and storage bins, maturity and quality evaluation of products which are fundamental to grain marketing and in predicting physical structure and chemical composition [13].

The porosity of xylopia aethiopica was found to be $52.6 \%$. The mean porosity for bitter kola nut and shell reported to be $35.60 \pm 0.97 \%$ and $40.70 \pm 1.21 \%$ [26].This is an indication that air circulation through the products will be more pronounced in xylopiaaethiopicacompared to bitter kola nut and shell. The porosity of any biomaterialprovides information on airflow, heat flow, Reynolds number in pneumatic and hydraulic handling and thermal diffusivity in drying.

Table-2. Mechanical properties xylopia aethiopica

\begin{tabular}{l|l|l}
\hline \multirow{2}{*}{ Properties } & \multicolumn{2}{|c}{ Fruit } \\
\cline { 2 - 3 } & Mean & Standard deviation \\
\hline Bulk density $\left(\mathrm{kg} / \mathrm{m}^{3}\right)$ & 389.31 & 11.09 \\
\hline True density $\left(\mathrm{kg} / \mathrm{m}^{3}\right)$ & 873.76 & 13.85 \\
\hline Porosity $(\%)$ & 52.60 & 4.39 \\
\hline Bio-yield force $(\mathrm{N})$ & 176.13 & 9.26 \\
\hline Deformation $(\mathrm{mm})$ & 2.47 & 0.11 \\
\hline Rupture force $(\mathrm{N})$ & 197.23 & 7.78 \\
\hline Compressive force $(\mathrm{MPa})$ & 5.23 & 0.65 \\
\hline
\end{tabular}

The average bio-yield force and deformation of xylopia aethiopica values were176.13 $\mathrm{N}$ and $2.47 \mathrm{~mm}$. The mean compressive force of xylopia aethiopica was 5.23 MPa. The mean rupture force needed to break the xylopia aethiopica was $197.23 \pm 7.78 \mathrm{~N}$. The corresponding rupture force required for bitter kola nut and shell on vertical position were $321.6 \pm 10.49$ and $24.0 \pm 1.05 \mathrm{~N}$ [33].

The mean static coefficients friction of xylopia aethiopica with four different structural materials including stainless steel, galvanized iron sheet, plywood sheet, rubber sheet, and plastic sheet were $0.31,0.47,0.560 .49$ and 
0.38 accordingly (Table 3). Stainless steel and plywood sheet had the lowest and highest static coefficient friction.This property is central for designing pneumatic conveying systems, screw conveyors, hoppers. This parameter is essential in calculating compressibility and flow behaviour of biological materials used for designing seed bins and other storage structures [34].The average angle of repose of xylopia aethiopica was $44.32^{\circ}$ (11.9). The static, dynamic coefficient of frictions and angle of repose is pertinent for the design of conveyor and hoppers for planting machines.

Table-3. Frictional properties of date palm fruit and kernel

\begin{tabular}{l|l|l}
\hline \multirow{2}{*}{ Properties } & \multicolumn{2}{|c}{ Fruit } \\
\cline { 2 - 3 } & Mean & Coefficient Variation \\
\hline Angle of repose $\left(^{\circ}\right)$ & 44.32 & 11.9 \\
\hline Coefficient of static friction & \multicolumn{2}{|}{} \\
\hline Stainless steel & 0.31 & 10.2 \\
\hline Galvanised iron sheet & 0.47 & 7.03 \\
\hline Plywood sheet & 0.56 & 9.42 \\
\hline Rubber sheet & 0.49 & 18.5 \\
\hline Plastic sheet & 0.43 & 12.9 \\
\hline Coefficient of dynamic friction & & \\
\hline Glass & 0.27 & 10.2 \\
\hline Galvanised iron sheet & 0.44 & 7.03 \\
\hline Plywood sheet & 0.53 & 9.42 \\
\hline Rubber sheet & 0.46 & 18.5 \\
\hline Plastic sheet & 0.35 & 12.9 \\
\hline
\end{tabular}

\section{Conclusion}

1. Some engineering properties of xylopia aethiopicasuch as length, width, thickness, arithmetic and geometric mean diameter, sphericity, surface area, 1000unit mass, spherity and aspect ratio porosity, true and bulk densities, angle of repose were evaluated.The average length, width, and thickness varied between 25.13 and 87.60 $\mathrm{mm}, 3.48$ and $5.79 \mathrm{~mm}$, and 2.14 and $4.78 \mathrm{~mm}$.

2. Arithmetic and geometric mean diameters for xylopia aethiopica ranged from 10.25 to $32.72 \mathrm{~mm}$. While square mean diameter and equivalent diameter varied from 3.67 to $6.82 \mathrm{~mm}$ and 6.55 to $17.65 \mathrm{~mm}$.

3. The average sphericity and aspect ratio of xylopia aethiopica as shown in Table 1 revealed $15.50 \%$ and $6.69 \%$.

5. The average bio-yield force and deformation of xylopia aethiopica values was $176.13 \mathrm{~N}$. The force required to commence rupture of xylopia aethiopicain the horizontal and vertical axes in loading process ranged from 133.03 $\mathrm{N}$ and $172.68 \mathrm{~N}$ respectively as shown in Table 2. The mean deformation value of xylopia aethiopica was $1.49 \mathrm{~mm}$. The mean compressive force of xylopia aethiopica was $5.23 \mathrm{MPa}$. The mean fracture force required to break the bitter kola nut and shell vertical position were $321.6 \pm 10.49$ and $24.0 \pm 1.05 \mathrm{~N}$.

6. Stainless steel recorded the lowest static and dynamic coefficient of friction among all the surfaces investigated.

\section{References}

[1] Erhirhie, E. O. and Moke, G. E., 2014. "Xylopia aethiopica, A review of its ethnomedicinal, chemical and pharmacological properties." America Journal Pharm Tech Res., vol. 4, pp. 21-36.

[2] Nnodim, J. K., Nwanjo, H. U., Okolie, N. J., Opara, A. U., Nwosu, D. C., OKoroiwu, D. J., Okorie, H., Nwadike, C. N., and Uduji, H. I., 2013. "Effects of xylopiaaethiopica fruits onreproductive hormonal level in rats." Global Journal of Medicinal Plant Research, vol. 1, pp. 29-31.

[3] Ogbonnia, S. O., Mbaka, G. O., Anyika, E. N., Emordi, J. E., and Nwakakwa, N., 2011. "An evaluation of acute and subchronic toxicities of a nigerian polyherbal tea remedy." Pak J Nutr, vol. 10,

[4] Rickert, K., Martinez, R. R., and Martinez, T. T., 1999. "Pharmacist knowledge of common herbal preparations." Proc West Pharmacol Soc, vol. 42, pp. 1-2.

[5] Alam, M. B., Hossain, M. S., Chowdhury, N. S., Mazumder, M. E. H., and Haque, M. E., 2011. "In vitro and in vivo antioxidant and toxicity evaluation of different fractions of oxalis corniculatalinn." $J$. Pharmacol Toxicol., vol. 6, pp. 337-348.

[6] Ekeanyanwu, R. C. and Tienajirhevwe, O. F., 2012. "Phytochemical analysis and in vitro anthelmintic potentials of xylopiaaethiopica, dunal." A. Rich (Annonacea) from Nigeria. IJBPAS, vol. 1, pp. 322-330.

[7] Ekpo, A., Agbor, R. B., Osuagwu, A. N., Ekanem, B. E., Okpako, E. C., and Urua, I. S., 2012. "Phytochemical and comparative studies of the stem bark and root of xylopia aethiopica, dunal." A. Rich. World Journal of Biological Research, vol. 5, pp. 41-44.

[8] Okorie, H., Nwadike, C. N., and Uduji, H. I., 2013. "Effects of xylopia aethiopica fruits on reproductive hormonal level in rats." Global Journal of Medicinal Plant Research, vol. 1, pp. 29-31.

[9] Orwa, C., Mutua, A., Kindt, R., Jamnadass, R., and Simons, A., 2009. "Agroforestree database, A tree reference and selection guide. Version." vol. 4, 
[10] Yapi, T., A., Boti, J. B., Ahibo, C. A., Bighelli, A., Castola, V., Casanova, J., and Tomi, F., 2012. "Chemical variability of the leaf essential oil of xylopiaaethiopica (dunal)." A.Rich.from Côte d'Ivoire. ChemBiodivers, vol. 9, pp. 2802-2809.

[11] Mohsenin, N. N., 1986. Physical properties of plant and animal materials. New York: Gordon and Breach Science Publishers.

[12] Davies, R. M., 2012. "Physical and mechanical properties of palm fruit, kernel and nut." Journal of Agricultural Technology, vol. 8, pp. 1459-1468.

[13] Irtwange, S. V. and Igbeka, J. C., 2002. "Some physical properties of two African yam bean (Sphenostylissteno carpa) accessions and their interrelations with moisture content." Applied Engineering in Agriculture, vol. 18, pp. 567-576.

[14] Tavakoli, H., Rajabipour, A., and Mohtasebi, S. S., 2009. "Moisture-dependent some engineering properties of soybean grains. Agricultural engineering international." The CIGR EJournal. Manuscript, vol. 1110, pp. $2-14$.

[15] Adebowale, A. A., Sanni, L. O., Owo, H. O., and R., K. O., 2011. "Effect of variety and moisture content on some engineering properties of paddy rice." Journal of Food Science and Technology, vol. 48, pp. 551559.

[16] Gebreselassie, T. R., 2012. "Moisture dependent physical properties of cardamom, elettaria cardamomum." Seed Agric. Eng. Int. CIGR Journal, vol. 14, pp. 108-115.

[17] Ehiem, J. C. and Simonyan, K. J., 2012. "Physical properties of wild mango fruit and nut Int." Agrophysic, vol. 26, pp. 95-98.

[18] Odesanya, K. O., Adebiyi, K. A., and Salau, T. A. O., 2015. "Estimation of engineering parameters for the development of a groundnut decorticator." International Journal of Novel Research in Engineering and Applied Sciences, vol. 2, pp. 2-25.

[19] Koocheki, A., Razavi, S. M. A., Milani, E., Moghadan, T. M., Abedini, M., Alamatiyan, S., and Izadikhah, S., 2007. "Physical properties of watermelon seed as a function of moisture content and variety." Int. Agrophysics, vol. 21, pp. 349-359.

[20] Milani, E., Razavi, S. M. A., Koocheki, A., Nikzadeh, V., Vahedi, N., MoeinFord, M., and GholamhosseinPour, A., 2007. "Moisture dependent physical properties of cucurbit seeds." Int.Agrophysics, vol. 21, pp. 157- 168 .

[21] Galedar, M. N., Jafari, A., and Tabatabaeefa, A., 2008. "Some physical properties of wild pistachio nut and kernel as a function of moisture content." Journal of Physics and Environmental and Agricultural Sciences, vol. 22, pp. 117-124.

[22] Davies, R. M., 2009. "Some physical properties of groundnut grains." Research Journal of Applied Sciences, Engineering and Technology, vol. 1, pp. 10-13.

[23] Davies, R. M., 2009. "Engineering properties of three varieties of melon seeds as potential for development of processing machine." AdvanceJournal of Food Sciences and Technology, vol. 2, pp. 63-66.

[24] Davies, R. M., 2016. "Some post harvest engineering properties of hog plumfruit and nut (spondias mombins) in relation to design of processing machines." Journal of Scientific Research in Engineering \& Technology, vol. 1, pp. 1-19.

[25] Erdogan, D., Guner, M., Dursun, E., and Gezer, I., 2003. "Mechanical harvesting apricots." Biosystems Eng., vol. 85, pp. 19-28.

[26] Davies, R. M. and Mohammed, U. S., 2013. "Engineering properties of bitter Kola nuts and shell as potentials for development processing machines." International Journal of ScientificResearch in Environmental Sciences, vol. 1, pp. 337-343.

[27] Omobuwajo, T. O., Sanmi, L. A., and Olajide, J. O., 2000. "Physical properties of ackee apple seeds." Journal of Food Engineering, vol. 45, pp. 43-48.

[28] Davies, R. M. and Zibokere, D. S., 2011. "Some physical properties of gbafilo (chrysobalanus icaco) fruits and kernels preparatory to primary processing." International Journal of Agricultural Research, vol. 6, pp. 848-855.

[29] Oyelade, O. J., Odugbenro, P. O., Abioye, A. O., and Raji, N. I., 2005. "Some physical properties of african starapple (chrysophyllumalibidum) seeds." Journal of Food Engineering, vol. 67, pp. 435-440.

[30] Dash, A. K., Pradhan, R. C., Das, I. M., and Naik, S. N., 2008. "Some physical properties of simabouba fruit and kernel." Int. Agrophysics, vol. 22, pp. 111-116.

[31] Dutta, S. K., Nema, V. K., and Bhardwaj, R. K., 1988. "Physical properties of gram." Journal of Agricultural Engineering Research, vol. 39, pp. 259-268.

[32] Shepherd, H. and Bhardwaj, R. K., 1986. "Moisture dependent Physical properties of pigeon pea." Journal of Agricultural Engineering Research, vol. 35, pp. 227-234.

[33] Tabatabaeefa, A., 2003. "Moisture-dependent physical properties of wheat." Int. Agrophysics, vol. 12, pp. 207-211.

[34] Kaleemullah, S. and Gunasekar, J. J., 2002. "Moisture dependent physical properties of areca nut kernels." Biosystem Engineering, vol. 52, pp. 331-338. 